\title{
Urushiol (Poison Ivy)-triggered Suppressor T Cell Clone Generated from Peripheral Blood
}

Richard S. Kalish and Chikao Morimoto

Division of Tumor Immunology, Dana-Farber Cancer Institute, Boston, Massachusetts 02115

\begin{abstract}
Allergic contact dermatitis to Toxicodendron radicans (poison ivy) is mediated by the hapten urushiol. An urushiol-specific, interleukin 2 (IL-2)-dependent $T$ cell clone (RLB9-7) was generated from the peripheral blood of a patient with a history of allergic contact dermatitis to $T$. radicans. This clone proliferated specifically to both leaf extract and pure urushiol. Although the clone had the phenotype $\mathrm{CD3}^{+} \mathrm{CD4}^{+} \mathrm{CD8}^{+}$, proliferation to antigen was blocked by anti-CD8 and anti-HLA-A, $B, C$ but not by anti-CD4, suggesting that CD4 was not functionally associated with the $T$ cell receptor. Furthermore, studies with antigen-presenting cells from MHC-typed donors indicated that the clone was MHC class 1 restricted. RLB9-7 was WT31 positive, indicating it bears the $\alpha \beta$ T cell receptor. The clone lacked significant natural killer cell activity and produced only low levels of IL-2 or $\gamma$-interferon upon antigen stimulation. Addition of RLB9-7 to autologous peripheral blood mononuclear cells in the presence of urushiol inhibited the pokeweed mitogen-driven IgG synthesis. This suppression was resistant to irradiation (2,000 rad) and was not seen when RLB9-7 was added to allogeneic cells, even in the presence of irradiated autologous antigen-presenting cells, suggesting that suppression was MHC restricted and not mediated by nonspecific soluble factors. However, RLB9-7 cells in the presence of urushiol inhibited the synthesis of tetanus toxoid-specific IgG by autologous lymphocytes, indicating that the suppression, although triggered specifically by urushiol, was nonspecific.
\end{abstract}

\section{Introduction}

Allergic contact dermatitis to Toxicodendron radicans (rhus or poison ivy) has been shown to be a delayed hypersensitivity response to urushiol, a catechol with a C15 lipophilic tail $(1,2)$. Previous studies (3) have demonstrated that lymphocytes from patients with a recent history of allergic contact dermatitis to Toxicodendron radicans will proliferate in vitro to urushiolcoupled erythrocytes. This report describes the generation from peripheral blood of a urushiol-specific $\mathrm{T}$ cell clone with immunoregulatory properties.

Portions of this work have appeared in abstract form (1987. Clin. Res. 35:693A).

Address reprint requests to Dr. Kalish. Current address: Department of Dermatology, Box 98 UMHC/4-240 PWB, 420 Delaware Street, SE, Minneapolis, MN 55455-0392.

Received for publication 2 October 1987 and in revised form 24 February 1988.

J. Clin. Invest.

(c) The American Society for Clinical Investigation, Inc.

$0021-9738 / 88 / 09 / 0825 / 08 \quad \$ 2.00$

Volume 82, September 1988, 825-832
$T$ cell clones specific for nickel sulfate and cobalt chloride have been cloned from the peripheral blood $(4,5)$ and skin lesions (6) of sensitive patients. These clones, which were $\mathrm{CD}^{+}$, proliferated and produced both interleukin 2 (IL-2) and $\gamma$-interferon in response to antigen. It was hypothesized that these cells may be mediators of the delayed hypersensitivity response. There are additional literature reports describing the generation of $\mathrm{T}$ cell lines and clones from a large variety of human pathological lesions including autoimmune thyroiditis (7), plaques of multiple sclerosis (8), tumors (9), and kidney allografts undergoing rejection (10). Unfortunately, most of these studies are handicapped by the lack of a known relevant antigen. Exceptions include the cloning of lepromin-triggered $\mathrm{CD}^{+}$suppressor cells from lesions of lepromatous leprosy (11, 12) the cloning of hepatitis B virus-specific clones from livers exhibiting chronic active hepatitis B (13), and suppressor cells from peripheral blood of patients with acute EBV infectious mononucleosis (14).

This article reports on the generation of a urushiol-specific $\mathrm{T}$ cell clone from a donor with a history of allergic contact dermatitis to $T$. radicans. This clone proliferated specifically both to pure urushiol and to leaf extract. Addition of these cells to a pokeweed mitogen (PWM)-induced IgG synthesis system with autologous lymphocytes was found to suppress IgG production in the presence of urushiol but not in its absence. The properties of this urushiol-triggered nonspecific suppressor clone were further investigated and its potential role in downregulating delayed contact hypersensitivity is discussed.

\section{Methods}

Preparation of peripheral blood mononuclear cells (PBMC). Heparinized peripheral venous blood was separated into $\mathrm{PBMC}$ by centrifugation on Ficoll-Hypaque (Pharmacia Fine Chemicals, Piscataway, NJ) gradients, followed by washing. Sheep red blood cell receptor-positive $\left(E^{+}\right)^{1} T$ cells and receptor-negative $\left(E^{-}\right)$non- $T$ cells were isolated by rosetting followed by centrifugation over a Ficoll-Hypaque gradient and lysis of sheep red blood cells (SRBC) by ammonium chloride as described (15).

Production of IL-2-containing conditioned medium. Crude IL-2 preparations were generated by treatment of PBMC isolated from buffy coat from platelet donations with $4 \mu \mathrm{g} / \mathrm{ml}$ phytohemagglutinin (Burroughs Wellcome, Research Triangle Park, NC) and $(5 \mathrm{ng} / \mathrm{ml})$ TPA (Sigma Chemical Co., St. Louis, MO) for $4 \mathrm{~h}$ at $37^{\circ} \mathrm{C}\left(1 \times 10^{6}\right.$ cells $/ \mathrm{ml})$. The cells were then washed four times and resuspended $(1$ $\times 10^{6}$ cells $/ \mathrm{ml}$ ) in RPMI 1640 (Gibco, Grand Island, NY) containing $1 \%$ fetal calf serum (FCS, HyClone Labs, Logan, UT), $5 \mu \mathrm{g} / \mathrm{ml}$ gentamycin (Schering Corp., Kenilworth, NJ), and $4 \mathrm{mM}$ glutamine (Micro-

1. Abbreviations used in this paper: $\mathrm{E}^{+}$, sheep erythrocyte receptor-positive cell(s); $\mathrm{E}^{-}$, sheep erythrocyte receptor-negative cell(s); NK, natural killer cells. 
biological Associates, Bethesda, MD). The cells were cultured $72 \mathrm{~h}$ in 250- $\mathrm{cm}^{2}$ flasks (Corning Glass Works, Corning, NY), and the conditioned medium was harvested by centrifugation. Preparations were tested for their ability to maximally support the growth of IL-2-dependent human cell lines at a $10 \%$ final concentration of conditioned medium.

Generation of urushiol-specific T cell lines. PBMC from a urushiolsensitive donor, 11 months post rhus dermatitis, were sensitized in vitro against rhus extract $(1: 800)$ for $7 \mathrm{~d}$ in $10 \%$ human $\mathrm{AB}$ sera (Pel Freeze Biologicals, Rogers, AZ) supplemented RPMI 1640 medium containing $4 \mathrm{mM}$ glutamine, $25 \mathrm{mM}$ Hepes, gentamycin, and $0.5 \%$ sodium bicarbonate. The line was then carried in IL-2 media consisting of RPMI 1640 containing $10 \%$ FCS, $10 \%$ IL-2-containing conditioned medium ( $\sim 3 \mathrm{U} / \mathrm{ml}$ final concentration), $4 \mathrm{mM}$ glutamine, and $5 \mu \mathrm{g} / \mathrm{ml}$ gentamycin. After $2 \mathrm{wk}$ of culture the line was subcloned by limiting dilution in V-bottomed wells (96-well trays, Linbro, Flow Laboratories, Inc., McLean, VA) at one cell per well along with rhus extract (1:800) and autologous antigen-presenting cells (PBMC irradiated $5000 \mathrm{rad}, 1 \times 10^{5} /$ well) in IL-2 media. IL-2 medium was changed every $3 \mathrm{~d}$. After $3 \mathrm{wk}$ of growth, positive wells were expanded to U-bottom wells with the use of rhus extract and autologous irradiated PBMC. Growth of the T cell clones was maintained by feeding with IL-2 media every $3 \mathrm{~d}$ and addition of antigen with autologous irradiated PBMC as needed, generally every 2 wk. Clones derived in this manner have been cultured for up to 6 mo without loss of antigen specificity. The $\mathrm{CD}^{+}$tetanus toxoid-specific clone RT4, was also generated from PBL of the same donor using the above procedure, substituting tetanus toxoid for rhus extract. This clone specifically responded to tetanus toxoid in the presence of autologous irradiated PBMC and had tetanus toxoid-specific helper function.

Phenotype analysis. T cell clones were stained by indirect immunofluorescence with goat anti-mouse FITC (Tago, Inc., Burlingame, CA) and analyzed using an Epics $\mathrm{C}$ cytofluorograph (Epics Div., Coulter Electronics, Inc., Hialeah, FL). The monoclonal antibodies used included T11, T3, T4, T8, and NKH1 (Coulter Immunology, Hialeah, FL), as well as WT31 (Becton, Dickinson \& Co., Sunnyvale, CA).

Monoclonal antibodies. The antibodies 21Thy2D3 (T8A) IgG1, 19Thy5D7 (T4) IgG2, and 2Ad2A2 (anti-T3) IgM were developed in this laboratory. Anti-DR (949) (16) was a gift of Dr. Jerome Ritz (Dana-Farber Cancer Institute) and anti-HLA-A, B, C (W6/32, Sera Laboratories, Sussex, England) and anti-TCR $\alpha \beta$ chain (WT31, Becton Dickinson) were purchased.

Antigens. Rhus extract was made by extracting $18 \mathrm{gm} T$. radicans (poison ivy) leaves with $15 \mathrm{ml}$ of DMSO for $15 \mathrm{~h}$ at $4^{\circ} \mathrm{C}$. The material was then filtered through a $0.20-\mu \mathrm{m}$ filter, aliquotted, and stored at $-70^{\circ} \mathrm{C}$. Potency was determined by the ability to induce proliferation of PBMC from rhus-sensitive donors. It was found that a dilution of $(1: 800)$ to $(1: 1,200)$ gave maximal proliferation. PBMC from donors not sensitive to rhus or donors whose last episode of rhus dermatitis was over 12 mo previous did not respond.

Purified urushiol derived from $T$. radicans was the generous gift of Dr. H. Baer of the Bureau of Biologics, Food and Drug Administration, Bethesda, MD. Analysis of this material by gas chromatography showed no saturated side chains and a minimum of $95 \%$ catechol. The material was $85.1 \% \mathrm{C} 15$ triene, $10.2 \%$ combination mono- and diene, and $4.7 \% \mathrm{C} 17$ triene (Dr. H. Baer, personal communication).

Tetanus toxoid was obtained from the Massachusetts State Biological Laboratory and was used at a (1:200) final dilution.

Proliferation of IL-2-dependent cells. Responder cells were washed three times to remove IL-2 and resuspended in supplemented RPMI 1640 media containing 10\% human AB serum (Pel Freeze Biologicals), counted, and resuspended to $1 \times 10^{6}$ cells $/ \mathrm{ml}$ in the above media. Autologous PBMC to be used as antigen-presenting cells were irradiated 5000 rad by a Cesium Source (Gamma Cell 1000, Atomic Energy of Canada Limited), washed, and resuspended at $1 \times 10^{6}$ cells/ $\mathrm{ml}$ in the above human serum media. Responder cells were then added to round-bottom microtiter wells (96-well Nunc tray) $100 \mu$ l per well, four wells per group. The experimental variables were then added in a volume of $100 \mu \mathrm{l}$ per well. These included media alone, $5 \mathrm{U} / \mathrm{ml} \mathrm{IL-2,}$ and $20 \%$ autologous 5000 rad irradiated PBMC in the presence or absence of various antigens. The cells were cultured $24 \mathrm{~h}$ at $37^{\circ} \mathrm{C}$ in $7.5 \% \mathrm{CO}_{2}$ before addition of $\left[{ }^{3} \mathrm{H}\right]$ thymidine for a final $18-\mathrm{h}$ incubation. Cells were then harvested and $\left[{ }^{3} \mathrm{H}\right]$ thymidine uptake determined by scintillation counting.

Rhus extract (in DMSO) was used at a (1:800) final dilution. Pure urushiol, however, was added to proliferation assays in the form of urushiol-treated cell debris at a (1:10) dilution as described below, along with $5000 \mathrm{rad}$ irradiated PBMC $\left(2 \times 10^{5} / \mathrm{ml}\right)$ as a source of antigen-presenting cells.

Treatment of PBMC with urushiol. Urushiol was added to proliferation and IgG production assays in the form of treated PBMC. Ten million irradiated (5000 rad) PBMC were resuspended in $0.2 \mathrm{ml}$ of either DMSO, or a DMSO solution of pure urushiol at $0.08 \mathrm{mg} / \mathrm{ml}$. The cells were incubated at $37^{\circ} \mathrm{C}$ for $30 \mathrm{~min}$ and washed three times (centrifugation 2,000 rpm for $10 \mathrm{~min}$ ). The nonviable cell debris was then resuspended in $1.0 \mathrm{ml}$ of supplemented RPMI 1640 medium for addition to proliferation or IgG production assays at a (1:10) final dilution.

Cytotoxicity assay. Cultured T cells were tested for cytotoxicity against the natural killer cell (NK) target K562 as well as rhus extracttreated autologous $\left(\mathrm{E}^{-}\right)$cells to test for antigen-specific cytotoxicity. Target cells $\left(5 \times 10^{6}\right)$ were labeled with ${ }^{51} \mathrm{Cr}$ by incubation for $1 \mathrm{~h}$ at $37^{\circ} \mathrm{C}$ in $0.2 \mathrm{ml}$ of sodium chromate in saline $(1 \mathrm{mCi} / \mathrm{ml}$, New England Nuclear, Boston, MA). Targets were then washed and resuspended at $10^{5} / \mathrm{ml}$ in supplemented $10 \%$ human AB serum RPMI 1640. A standard 4-h cytotoxicity assay was performed as previously described using V-bottomed wells (17). Effectors were added at 20, 10, and 5 effector to target cell ratios. Standard deviations were consistently below $10 \%$ of the total counts per minute and spontaneous release varied between $15 \%$ and $25 \%$ of total release. Total release was determined by addition of $1 \%$ NP40 detergent in distilled water. Percent cytotoxicity was calculated by the formula: $\%$ cytotoxicity $=$ (counts per minute - spontaneous release)/(total release - spontaneous release) $\times 100$.

Antigen-induced lymphokine production. Production of IL-2 and $\gamma$-interferon were measured after stimulation with rhus extract. Cultured clone cells were washed extensively and incubated in 10\% human AB serum RPMI 1640 supplemented with $4 \mathrm{mM}$ glutamine and gentamycin with a (1:800) dilution of rhus extract. Cells were cultured in flat-bottomed 96-well microtiter trays (Costar, Cambridge, MA) with a final volume of $0.2 \mathrm{ml}$ per well, four wells per group at $1 \times 10^{5}$ cultured $\mathrm{T}$ cells per well. Autologous $\left(\mathrm{E}^{-}\right)$cells irradiated $5000 \mathrm{rad}$ were added at $1 \times 10^{4}$ cells per well as a source of antigen presenting cells. Culture supernatant was harvested daily for $3 \mathrm{~d}$ from sets of four wells and pooled for each group. IL-2 content was measured on each day but $\gamma$-interferon content was only measured in day 3 culture supernatant.

IL-2 content was assayed using $\left[{ }^{3} \mathrm{H}\right]$ thymidine uptake by an IL-2dependent cell line (CTLL-2). Recombinant IL-2 (Biogen, Cambridge, MA) standards were used to construct a standard curve. The $\boldsymbol{\gamma}$-interferon concentration was assayed using a solid-phase radioimmunoassay (RIA, Centocor, Malvern, PA) with recombinant $\gamma$-interferon standards.

$P W M$-induced $I g G$ production. PBMC $\left(5 \times 10^{5}\right.$ cells $\left./ \mathrm{ml}\right)$ were incubated in RPMI 1640 medium containing $20 \%$ FCS, $1 \%$ penicillinstreptomycin, $25 \mathrm{mM}$ Hepes (Microbiological Associates), 0.5\% sodium bicarbonate, $4 \mathrm{mM}$ glutamine and PWM at a final dilution of 1:100 (Gibco). Cloned T cells were added in variable numbers to 1.0 $\mathrm{ml}\left(5 \times 10^{5}\right.$ cells $)$ of PBMC, which were then aliquotted to U-bottomed microtiter wells (Nunc 96-well trays), $0.2 \mathrm{ml}$ per well, five wells per group. Antigen was added as indicated either as rhus extract $(1: 800)$ final dilution, tetanus toxoid (1:200) or antigen-treated PBMC (1:10) final dilution. Control cultures contained either DMSO (1:800) or DMSO-treated PBMC (1:10). After $7 \mathrm{~d}$ of incubation in 7.5\% $\mathrm{CO}_{2}$ at $37^{\circ} \mathrm{C}, 0.15 \mathrm{ml}$ of culture supernatant was harvested from each well and pooled. IgG content was then determined by competitive solid-phase RIA using ${ }^{125}$ I-human IgG as previously reported (18). All samples were assayed in triplicate and IgG was determined by reference to a standard curve generated concurrently. 

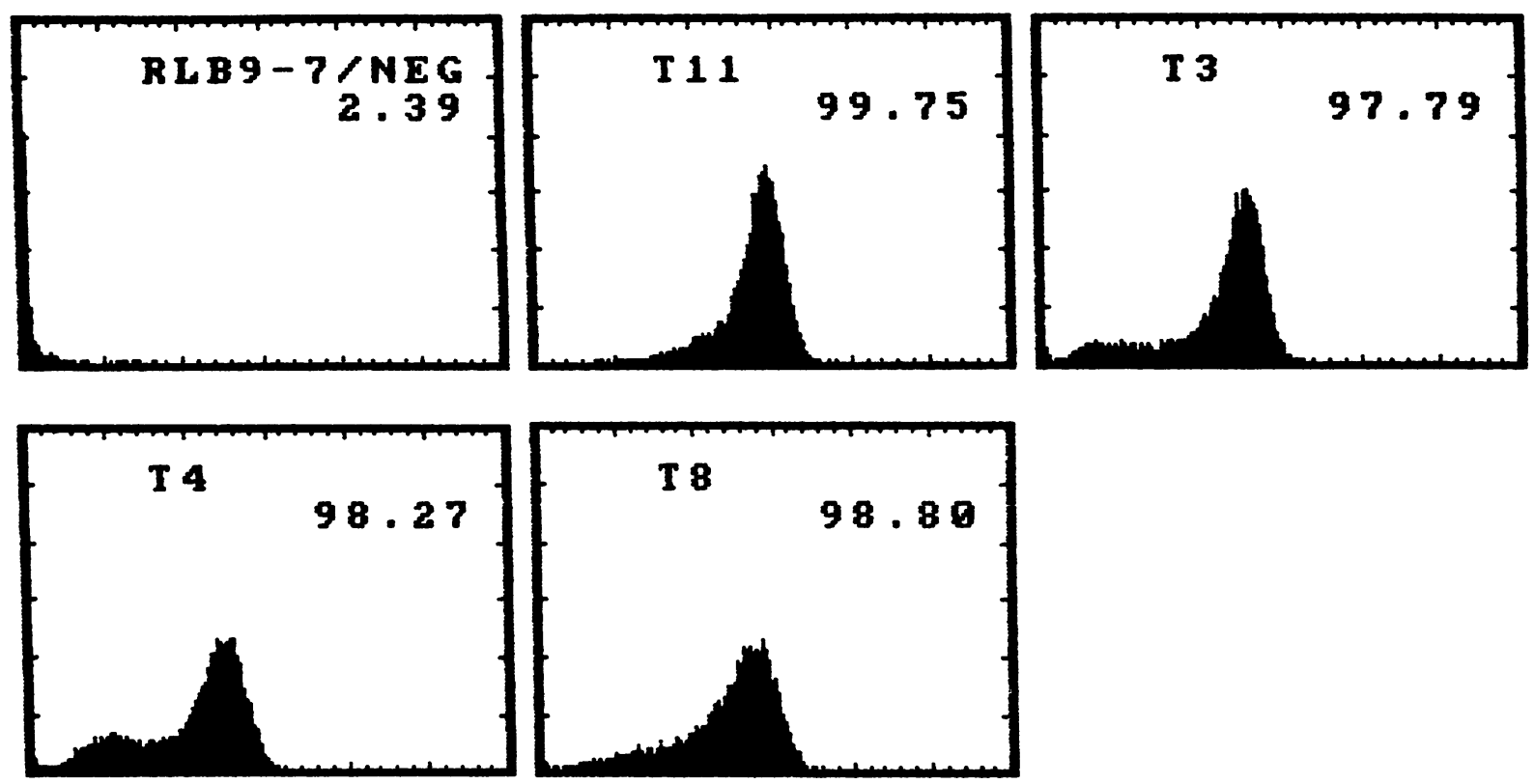

Figure 1. Phenotypic analysis of T cell clone RLB9-7. Cell surface expressions of CD2, CD3, CD4, and CD8 antigens were analyzed by indirect immunofluorescence on an Epics $\mathrm{C}$ cell sorter and expressed on a logarithmic scale. Each histogram shows the number of cells (ordinate) vs. fluorescence intensity (abscissa).

Tetanus toxoid-specific IgG production in vitro. The effects of RLB9-7 cells on in vitro tetanus toxoid-specific IgG production were assayed using autologous PBMC. An autologous tetanus toxoid-specific $\mathrm{CD4}^{+}$helper clone (RT4) was added to boost specific IgG production. PBMC $\left(1 \times 10^{6} / \mathrm{ml}\right)$ were incubated at $37^{\circ} \mathrm{C}$ in $7.5 \% \mathrm{CO}_{2}$ with tetanus toxoid (1:200 final dilution) and RT4 cells $\left(1 \times 10^{4} / \mathrm{ml}\right)$. RLB9-7 cells, rhus extract, DMSO, or antigen-treated PBMC were added as indicated. The cultures were incubated in U-bottomed microtiter wells (Nunc) with a final volume of $0.2 \mathrm{ml}$ per well and five wells per group. 20\% FCS supplemented RPMI 1640 medium was used as described for PWM-induced IgG synthesis. On day 4, the cells were washed three times to remove tetanus toxoid. This was performed by centrifuging the microtiter plates $1,000 \mathrm{rpm}$ for $10 \mathrm{~min}$ and changing the medium. Cells were then incubated an additional $5 \mathrm{~d}$ and media was harvested and pooled for RIA determination of tetanus toxoid-specific IgG. A control group containing no tetanus toxoid was included to provide a baseline.

The tetanus toxoid-specific RIA, which is a modification of a previously published assay for anti-KLH (19), was performed by absorbing tetanus toxoid $(0.1 \mathrm{ml}$ per well of $1: 200$ dilution) to polyvinyl chloride microtiter plates (Dynatech Corp., Alexandia, VA) for $15 \mathrm{~h}$ at $4^{\circ} \mathrm{C}$. The tetanus toxoid was then removed and the plates washed three times with PBS. The plates were then blocked with $1 \%$ BSA PBS for $1 \mathrm{~h}$ at $25^{\circ} \mathrm{C}$ and washed three times. Samples (culture media) were added, four wells per group, and incubated $6 \mathrm{~h}$ at $4^{\circ} \mathrm{C}$. Plates were washed four times with PBS and ${ }^{125} \mathrm{I}$-rabbit affinity-purified anti-human IgG (19) was added to the wells $\left(25 \mu \mathrm{l}\right.$ per well) for incubation at $4^{\circ} \mathrm{C}$ for $15 \mathrm{~h}$. Wells were then washed five times with PBS and counted in a gamma counter (LKB Instruments, Gaithersburg, MD).

\section{Results}

Generation of urushiol-specific $T$ cell clone RLB9-7. PBMC from a urushiol-sensitive donor were sensitized in vitro against rhus extract as described and cloned by limiting dilution, one cell per well. Clone RLB9 was chosen for further evaluation because of antigen specificity, good growth, and a high percentage of double-positive $\mathrm{T}^{+} \mathrm{T}^{+}$cells. It was further subcloned by limiting dilution one cell per well in 200 wells. Nine subclones grew sufficiently well to be characterized. Of these, RLB9-7 was chosen for further studies.

The phenotype of RLB9-7 was found to be T11 (99\%), T3 (98\%), T4 (98\%), and T8 (99\%) (Figure 1). This phenotype was found to be stable over $3 \mathrm{mo}$. The clone was also positive (89\%) for WT31, which recognizes the $\alpha \beta$ chain T cell receptor (Fig. 2).

Urushiol-specific proliferation of RLB9-7. RLB9-7 cells were washed free of IL-2 and added to proliferation assays using irradiated autologous PBMC as antigen-presenting cells. As shown in Table I, RLB9-7 proliferated in response to both rhus extract and pure urushiol. However, no response was seen to tetanus toxoid, although the donor was tetanus toxoid sensitive. DMSO was included as a control for the diluent and irradiated PBMC alone were included as a control for autoreactivity. Neither PBMC or DMSO induced a response significantly different from the media control.

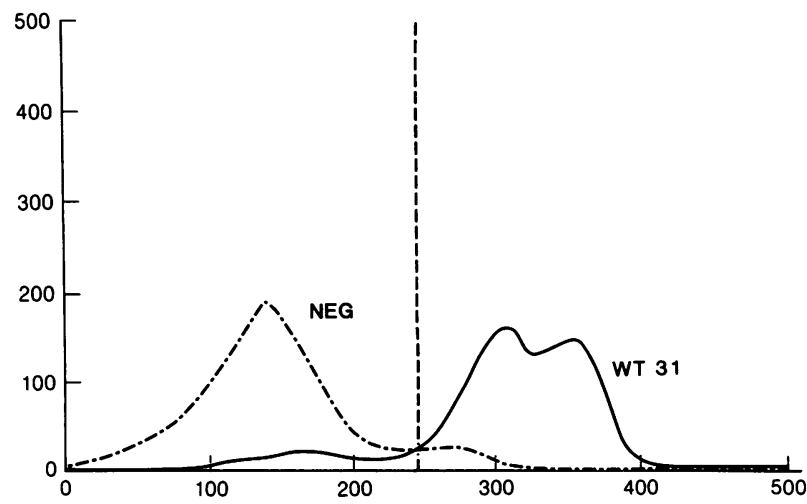

Figure 2. Cell surface expression of WT31 on clone RLB9-7. Antigen expression was analyzed by indirect immunofluorescence on a FACS cytofluorograph and expressed on a logarithmic scale. (Solid line) staining with WT31 (89\% positive); (broken line) staining with negative control. 
Urushiol in this system acted as an antigen and not as a mitogen. This is supported first by the finding that many clones did not respond to urushiol and also by the inability of PBMC from nonsensitive donors to respond to urushiol (data not shown). This later point has been well established by Byers et al. (3). The nonmitogeneity of urushiol was important to establish because it has been reported that urushiol can induce murine sponge aggregation in a manner similar to phorbol esters, which are believed to act on the sponge by activation of protein kinase $\mathrm{C}(20)$.

Antigen recognition requirements of $R L B 9-7$ cells. Since RLB9-7 is a $\mathrm{T}^{+} \mathrm{T}^{+}\left(\mathrm{CD}^{+} \mathrm{CD}^{+}\right)$double-positive cell, it is of interest to determine which surface structures are involved in antigen recognition. For this reason proliferation assays were performed in the presence of various monoclonal antibodies to surface structures known to be relevant to antigen recognition (Table II). Anti-T3 was able to completely abrogate the proliferation response, as were anti-T8 and anti-HLA-A, B, C. In contrast, anti-T4 had no effect on proliferation. Anti-DR had a mild inhibitory effect which may result from interaction with the RLB9-7 cells which are DR ${ }^{+}$. In other experiments, antiT3 (2Ad2A2), anti-HLA-A, B, C (W6/32), and anti-T8 (21Thy2D3) were shown to block both proliferation and cytotoxicity of an alloantigen-specific T8 clone, and anti-T3 (2Ad2A2), anti-DR (949) and anti-T4 (19Thy5D7) and were shown to block both proliferation and cytotoxicity of an alloantigen-specific T4 clone (21). Thus, despite the presence of the T4 molecule on the cell surface, RLB9-7 behaves as a T8 clone. One may surmise that these cells are class I MHC restricted and use the T8 molecule in cellular interactions. Alternate explanations which will be discussed later include downregulation of cells by anti-T4 or anti-T8.

In order to further establish the antigen recognition requirements of RLB9-7 cells, PBMC from a panel of MHCtyped donors were tested for the ability to present antigen. Several of the donors for this purpose were identified from the records maintained by Dr. Nancy Reinsmoen and Dr. Fritz Bach (University of Minnesota). It was found that antigen-specific proliferation best correlated with shared MHC class I antigens on the antigen-presenting cell (Table III). Thus, al-

Table I. Antigen-specific Proliferation of RLB9-7

\begin{tabular}{lrr}
\hline & Experiment 1 & Experiment 2 \\
\hline \multicolumn{3}{c}{$c p m \times 10^{-3}$} \\
Media & \multicolumn{3}{c}{$0.1(0.1)$} & $0.3(0.1)$ \\
IL-2 & $63.3(0.9)$ & $35.8(1.4)$ \\
PBMC & $0.6(0.3)$ & $0.2(0.1)$ \\
Rhus extract & $48.9(2.1)$ & $12.5(1.5)$ \\
Urushiol & $33.9(1.1)$ & $4.4(0.3)$ \\
DMSO & $1.0(0.1)$ & $0.3(0.1)$ \\
Tetanus toxoid & $2.0(0.3)$ & $0.3(0.1)$ \\
\hline
\end{tabular}

RLB9-7 cells were extensively washed and cultured $\left(1 \times 10^{5}\right.$ cells per well) with either media alone, IL-2, 5000 rad irradiated PBMC (2 $\times 10^{4}$ per well) or irradiated PBMC + antigen as shown. Urushiol and DMSO were added in the form of treated PBMC as described. [ ${ }^{3} \mathrm{H}$ ] Thymidine was added at $24 \mathrm{~h}$ and cells were harvested at $36 \mathrm{~h}$. Values in parentheses are SEM.
Table II. Monoclonal Antibody Blocking of RLB9-7 Proliferation

\begin{tabular}{lrr}
\hline \multicolumn{1}{c}{ Monoclonal antibody } & Experiment 1 & Experiment 2 \\
\hline & \multicolumn{2}{c}{$c p m \times 10^{-3}$} \\
Negative ascites & $50.9(3.2)$ & $14.1(0.7)$ \\
Anti-T3 (2Ad2) & $0.6(0.1)$ & $0.6(0.2)$ \\
Anti-T4 (19Thy) & $50.9(5.3)$ & $12.4(0.4)$ \\
Anti-T8 (21Thy) & $0.7(0.1)$ & $0.5(0.1)$ \\
Anti-DR (949) & $37.4(4.0)$ & $8.3(1.3)$ \\
Anti-HLA-A,B,C (W6/32) & $2.4(1.0)$ & $0.3(0.1)$ \\
& & \\
\hline
\end{tabular}

T cells were incubated $\left(1 \times 10^{5}\right.$ per well) with rhus extract (1:800), $5000 \mathrm{rad}$ irradiated PBMC $\left(2 \times 10^{4} / \mathrm{ml}\right)$ and monoclonal antibody ascites $(1: 100)$ as shown. $\left[{ }^{3} \mathrm{H}\right]$ Thymidine was added at $24 \mathrm{~h}$ and the cells were harvested $12 \mathrm{~h}$ later. Values in parentheses are SEM.

though RLB9-7 is $\mathrm{CD}^{+}{ }^{+} \mathrm{CD} 8^{+}$, it is $\mathrm{MHC}$ restricted to a class I determinant and behaves as a $\mathrm{CD}^{+}$cell.

Urushiol-specific suppression of PWM-induced IgG. In order to determine the immunoregulatory effects of RLB9-7, the cells were washed free of IL-2 and added to autologous PBMC in a PWM-induced IgG system. IgG production was then measured by solid-phase RIA. RLB9-7 cells were added to $1 \mathrm{ml}$ of PBMC $\left(5 \times 10^{5} / \mathrm{ml}\right)$ in ratios of $(1: 50),(1: 500)$, and $(1: 5,000)$. Cultures were performed in the presence of urushiol or DMSO treated PBMC (Table IV). It was found that RLB9-7 cells had little effect on IgG production in the absence of antigen. In additional experiments (data not shown), it was found that RLB9-7 cells were unable to provide help for autologous non-T cells for the production of IgG in response to PWM. However, in the presence of urushiol, RLB9-7 cells induced suppression of IgG synthesis in a dose-dependent manner. This suppression was not seen when tetanus toxoid was substituted for urushiol. In additional experiments not shown, rhus extract also induced RLB9-7 cells to suppress IgG production. These data, which are representative of four experiments, indicate that RLB9-7 suppresses PWM-induced IgG production by autologous cells when triggered by urushiol or rhus extract. RLB9-7 cells induced 96\% suppression at a 1:50

Table III. MHC Requirements for RLB9-7 Proliferation

\begin{tabular}{clc}
\hline Donor* & \multicolumn{1}{c}{ MHC $^{*}$} & Proliferation \\
\hline & & $c p m \times 10^{-3}$ \\
Autologous & A24 A32 BW52 BW61 CW2 DR2 DR4 & $10.8^{8}$ \\
2 & A24 A31 BW52 BW61 DR9 DR4 & 11.2 \\
3 & A1 A9 B8 B18 DR3 DR4 & 2.0 \\
4 & A2 A11 BW22 CW1 DR4 & 2.3 \\
5 & A2 A11 BW52 B35 CW3 DR2 DRW53 & 1.5 \\
\hline
\end{tabular}

RLB9-7 cells were cultured $\left(1 \times 10^{5}\right.$ per well) with 5000 rad irradiated PBM antigen-presenting cells $\left(2 \times 10^{4}\right.$ per well) at four wells per group, in the presence or absence of urushiol (rhus extract 1:800). $\left[{ }^{3} \mathrm{H}\right]$ Thymidine was added at $24 \mathrm{~h}$ and cells harvested at $36 \mathrm{~h}$. In all cases, RLB9-7 cells incubated with PBMC in the absence of rhus extract resulted in $<1.0 \times 10^{3} \mathrm{cpm}$.

* Donor refers to source of irradiated antigen-presenting cells.

‡ MHC: alleles shared with autologous donor are underlined.

${ }^{8}$ SEM are $<20 \%$. 
Table IV. Urushiol-specific Suppression of PWM-induced IgG

\begin{tabular}{cccr}
\hline RLB9-7 & DMSO & Urushiol & Tetanus toxoid \\
\hline & & IgG $\mu g / \mathrm{ml}$ & \\
Experiment 1 & & & \\
PBMC alone & $16.5(0.5)$ & $10.0(0.5)$ & $9.5(0.4)$ \\
$+10^{4} / \mathrm{ml}$ & $16.2(1.5)$ & $0.4(0.8)$ & $7.4(1.0)$ \\
$+10^{3} / \mathrm{ml}$ & $12.0(0.2)$ & $2.7(0.1)$ & $13.5(0.5)$ \\
$+10^{2} / \mathrm{ml}$ & $14.2(0.4)$ & $7.5(0.1)$ & $7.1(0.2)$ \\
Experiment 2 & & & \\
PBMC alone & $13.0(1.0)$ & $15.0(0.4)$ & $10.0(0.8)$ \\
$+10^{4} / \mathrm{ml}$ & $14.0(1.0)$ & $1.6(0.2)$ & $9.5(0.5)$ \\
$+10^{3} / \mathrm{ml}$ & $13.0(0.4)$ & $9.0(0.8)$ & $9.0(0.6)$ \\
$+10^{2} / \mathrm{ml}$ & $14.0(1.0)$ & $12.0(0.4)$ & $9.0(0.4)$ \\
& & & \\
\hline
\end{tabular}

PBMC $\left(5 \times 10^{5} / \mathrm{ml}\right)$ were cultured with PWM and RLB9-7 cells for $7 \mathrm{~d}$. IgG was assayed by RIA. Urushiol and DMSO were added as treated PBMC as described.

Values in parentheses are SEM.

ratio of RLB9-7 cells to PBM and 73\% suppression at a 1:500 ratio of RLB9-7 cells to PBM. The ability to suppress at high ratios of RLB9-7 cells to responder cells suggests that suppression was not the result of crowding or media depletion. To further rule out this possibility, RLB9-7 cells were irradiated to prevent proliferation. It was found in three experiments (Table V) that the irradiation of RLB9-7 cells with $2000 \mathrm{rad}$ did not abrogate suppression even at ratios of (1:50) and (1:500), further substantiating the evidence that RLB9-7-induced suppression does not result from depletion of media or growth factors.

Cytotoxicity of RLB9-7 cells. Since NK cells are known to nonspecifically suppress many in vitro immune responses (22), RLB9-7 cells were assayed for the ability to lyse NK-sensitive targets. RLB9-7 cells were tested in a 4-h ${ }^{51} \mathrm{Cr}$-release cytotoxicity assay against the NK targets K562, Rex, and Molt 4 using effector/target ratios of 20,10 , and 5 . In three assays the highest cytotoxicity detected at a (20:1) effector/target ratio was $12 \%(12 \%, 6 \%, 1 \%)$. This is negligible compared to the $70-80 \%$ cytotoxicity detected in NK-positive T cell lines tested concurrently. These results are also supported by a $<10 \%$ expression of the NK cell marker NKH1 (23).

RLB9-7 cells were also tested for cytotoxicity against autologous $\left(\mathrm{E}^{-}\right)$cells and rhus extract-treated autologous $\left(\mathrm{E}^{-}\right)$cells. In three experiments the levels of cytotoxicity against the rhus

Table V. Radioresistance of RLB9-7 Suppression

\begin{tabular}{|c|c|c|c|c|}
\hline & \multicolumn{2}{|c|}{ Experiment 1} & \multicolumn{2}{|c|}{ Experiment 2} \\
\hline & Control & $2000 \mathrm{rad}$ & Control & $2000 \mathrm{rad}$ \\
\hline & \multicolumn{4}{|c|}{$I g G \mu g / m l$ by $R I A$} \\
\hline PBMC + urushiol & $15.0(0.4)$ & $15.0(0.4)$ & $3.5(0.2)$ & $3.5(0.2)$ \\
\hline +RLB9-7 $10^{4} / \mathrm{ml}$ & $1.6(1.6)$ & $2.5(0.2)$ & $0.1(0.1)$ & $0.1(0.3)$ \\
\hline +RLB9-7 $10^{3} / \mathrm{ml}$ & $9.0(0.8)$ & $13.0(0.6)$ & $1.8(0.1)$ & $1.1(0.3)$ \\
\hline +RLB9-7 $10^{2} / \mathrm{ml}$ & $12.0(0.4)$ & $15.0(1.0)$ & $4.5(0.1)$ & $2.3(0.2)$ \\
\hline
\end{tabular}

PBMC $\left(5 \times 10^{5} / \mathrm{ml}\right)$ were incubated with PWM and rhus for $7 \mathrm{~d}$. RLB9-7 cells were either unirradiated or irradiated 2000 rad. Urushiol was added to all groups. Values in parentheses are SEM. extract-treated cells at a $(20: 1)$ effector/target ratio were $(4 \%$, $1 \%, 0 \%$ ) suggesting this clone does not exhibit antigen-specific cytotoxicity or autocytotoxicity.

RLB 9-7 cells do not suppress allogeneic PBMC in the presence of autologous antigen-presenting cells. Proliferation of RLB9-7 cells was found to require antigen-presenting cells from either the autologous donor or a donor closely matched for class I MHC (Table III). For this reason, it was expected that RLB9-7 cells would not suppress IgG production by allogeneic PBMC (Table VI). The more critical experiment was whether RLB9-7 cells would suppress allogeneic PBM in the presence of autologous antigen-presenting cells ( 5000 rad irradiated PBMC). It was found in three experiments that, as expected, RLB9-7 did not suppress PBMC from unrelated donors in the presence of urushiol. In addition, this defect was not overcome by the addition of irradiated autologous antigen-presenting cells at a concentration sufficient to induce antigen-specific proliferation. This suggests that suppression may be mediated by direct autologous cellular interaction rather than nonspecific suppressor factors, since the autologous antigen-presenting cells should be sufficient to induce activation and lymphokine production by the RLB9-7 cells.

Antigen-induced lymphokine production by RLB9-7 cells. In order to determine the levels of IL- 2 and $\gamma$-interferon produced by RLB9-7 cells, the cells were washed and cultured in $10 \%$ human serum RPMI 1640 as described, in the presence of rhus extract $(1: 800)$ and 5000 rad irradiated autologous $\left(\mathrm{E}^{-}\right)$ antigen-presenting cells. Culture supernatants were harvested from replicate cultures on days 1, 2, and 3 and both IL-2 and $\gamma$-interferon content were measured. It was found that both IL-2 and $\gamma$-interferon were produced in small quantities (1.4 $\mathrm{U} / \mathrm{ml} \mathrm{IL-2} \mathrm{maximum} \mathrm{at} 24 \mathrm{~h} ; 6 \mathrm{U} / \mathrm{ml} \gamma$-interferon at $72 \mathrm{~h}$ ). Control cultures consisting of irradiated antigen-presenting cells plus antigen produced undetectable $(<0.3 \mathrm{U} / \mathrm{ml})$ levels of each lymphokine. By contrast, values reported in the literature for IL-2 and $\gamma$-interferon producing clones frequently exceed

Table VI. RLB9-7 Cells Do Not Suppress Allogeneic PBMC

\begin{tabular}{cccc}
\hline & \multicolumn{3}{c}{ Source of responding cells } \\
\cline { 2 - 4 } RLB9-7 & Autologous & Allogeneic & $\begin{array}{c}\text { Allogeneic } \\
\text { + autologous APC* }\end{array}$ \\
\multicolumn{4}{c}{$I g G \mu g / m l$} \\
Experiment 1 & & & \\
- & $15.0(0.4)$ & $8.0(0.4)$ & $7.0(0.6)$ \\
$1 \times 10^{4}$ & $1.6(0.2)$ & $9.5(0.5)$ & $14.0(0.5)$ \\
$1 \times 10^{3}$ & $9.0(0.8)$ & $9.0(0.4)$ & $12.0(1.0)$ \\
Experiment 2 & & & $2.3(0.1)$ \\
- & $2.3(0.1)$ & $1.4(0.2)$ & $3.0(0.1)$ \\
$1 \times 10^{4}$ & $0.2(0.3)$ & $4.0(0.1)$ & $1.9(0.2)$ \\
$1 \times 10^{3}$ & $0.7(0.1)$ & $1.5(0.3)$ & \\
\hline
\end{tabular}

Responder cells $\left(5 \times 10^{5} \mathrm{PBMC} / \mathrm{ml}\right)$ were incubated with $\mathrm{PWM}$ and urushiol-treated irradiated PBMC for $7 \mathrm{~d}$ and $\mathrm{IgG}$ production was determined by RIA. Irradiated ( $5000 \mathrm{rad}$ ) autologous PBMC ( 1 $\times 10^{5} / \mathrm{ml}$ ) were added as a source of antigen-presenting cells (APC) as indicated.

* 5000 rad irradiated autologous PBMC added as antigen presenting cells.

Values in parentheses are SEM. 
$100 \mathrm{U} / \mathrm{ml}$ under similar conditions (4). In addition, a CD8 ${ }^{+}$ urushiol-specific clone (RLA-2) from the same donor which produced $120 \mathrm{U} / \mathrm{ml} \gamma$-interferon in response to rhus extract did not suppress IgG production (data not shown). This suggests that $\gamma$-interferon production is not the mediator of antigen-triggered suppression. Conditioned medium from urushiol-stimulated RLB9-7 cells $\left(2 \times 10^{6} / \mathrm{ml}\right.$ in $20 \%$ FCS RPMI 1640) was also added to the PWM assay. However, no suppression was detected.

Effect of RLB9-7 on tetanus toxoid-specific IgG. The specificity of suppression by RLB9-7 remains to be defined. Since all the preceding experiments used nonspecific PWM-induced IgG synthesis as an assay system, it could be argued that the suppression is nonspecific. However, the possibility remains that PWM stimulates the cells in a manner that mimics antigen-specific stimulation. For this reason, it was decided to investigate the effect of RLB9-7 cells on the induction of tetanus toxoid-specific IgG in vitro. Because the RLB9-7 donor was sensitive to tetanus toxoid and suppression appears to be MHC restricted, autologous PBMC were used. PBMC were cultured $9 \mathrm{~d}$ with tetanus toxoid and RT4, an autologous tetanus toxoid-specific $\mathrm{CD}^{+}$helper clone, as described. Tetanus toxoid-specific IgG was then determined by RIA.

In the absence of tetanus toxoid, a background of $551 \mathrm{cpm}$ was bound. However, the addition of tetanus toxoid boosted cpm bound to 8,474 (Table VII). RLB9-7 cells did not suppress in the absence of rhus but rather gave a boost in cpm bound. The addition of rhus extract resulted in a decrease of cpm bound from 6,061 to 2,944 . Thus, RLB9-7 was able to induce suppression of an unrelated antigen-specific antibody response, indicating that although RLB9-7 triggering is antigen specific, the suppression mechanism is nonspecific.

\section{Discussion}

In this article we describe the generation of a urushiol-triggered $\mathrm{CD}^{+}{ }^{+} \mathrm{CD} 4^{+} \mathrm{CD}^{+}$suppressor clone from the peripheral blood of an urushiol-sensitive donor. Urushiol is the hapten responsible for allergic contact dermatitis to $T$ radicans or rhus (poison ivy) $(1,2)$. The suppressor clone, RLB9-7, proliferated both to leaf extract and to pure urushiol but not to tetanus toxoid or autologous lymphocytes. Addition of this clone to a PWM-induced IgG synthesis system inhibited IgG production in the presence of urushiol but not in its absence, indicating

Table VII. Effect of RLB9-7 and Rhus Extract on Tetanus Toxoid-specific IgG

\begin{tabular}{lcc}
\hline & No rhus & Rhus \\
\hline & \multicolumn{2}{c}{$c p m$} \\
No tetanus toxoid & $551(22)$ & ND \\
Tetanus toxoid & $8,474(184)$ & $6,061(76)$ \\
+RLB9-7 $10^{4} / \mathrm{ml}$ & $12,496(278)$ & $2,944(61)$ \\
+RLB9-7 $10^{3} / \mathrm{ml}$ & $7,303(300)$ & $3,810(190)$ \\
+RLB9-7 $10^{2} / \mathrm{ml}$ & $7,795(556)$ & $6,191(214)$ \\
\hline
\end{tabular}

Autologous PBMC $\left(1 \times 10^{6} / \mathrm{ml}\right)$ were incubated for $9 \mathrm{~d}$ with 1 $\times 10^{4} / \mathrm{ml}$ tetanus toxoid-specific $\mathrm{CD}^{+}$clone cells in the presence of tetanus toxoid (+/-) rhus extract or RLB9-7. Tetanus toxoid-specific IgG was determined by RIA. Values in parentheses are SEM. that suppression was triggered by antigen. However, it is unlikely that this suppression was the result of crowding or depletion of nutrients (e.g., IL-2) as suppression was observed at ratios of (1:50) and (1:500). In addition, suppression was resistant to irradiation of RLB9-7 cells with $2000 \mathrm{rad}$.

This antigen-specific suppressor clone appears to utilize the $\alpha \beta$ T cell receptor and recognize antigen in the context of class I MHC. Antigen-specific suppressor clones bearing the $\alpha \beta \mathrm{T}$ cell receptor have been previously cloned from skin lesions of lepromatous leprosy (24).

Double-positive $\mathrm{CD}^{+} \mathrm{CD}^{+}$human clones have reported previously (10). However, unlike RLB9-7, they did not exhibit antigen-specific proliferation. Although RLB9-7 cells were $\mathrm{CD} 4^{+} \mathrm{CD} 8^{+}$, proliferation was inhibited by anti-CD8 but not anti-CD4, suggesting that RLB9-7 cells behave as $\mathrm{CD}^{+}$cells and recognize antigen in the context of class I MHC antigens. This was further supported by the finding that class I MHC matched donors were capable of presenting antigen for specific proliferation of clone cells. An alternate explanation is that anti-CD8 is capable of downregulating RLB9-7 proliferation as has been previously suggested for CD8 cytotoxicity (25). If this is the case, it should be noted that RLB9-7 proliferation was not downregulated by anti-CD4, despite evidence that anti-CD4 is capable of inhibiting CD4 cells $(26,27)$ suggesting that in RLB9-7 cells, CD4 is "uncoupled" from the inhibitory mechanism. Lack of functional association of CD4 and CD3$\mathrm{Ti}$ has been previously reported in a $\mathrm{CD} 4^{+} \mathrm{CD} 8^{+}$clone (27). However, this is the first such report utilizing antigen-specific proliferation. This result is in contrast to that of Jones et al. (28), who reported a murine $\mathrm{CD} 4^{+} \mathrm{CD} 8^{+}$clone specifically cytolytic for ovalbumin in the context of self I-A. Cytotoxicity of this clone was readily inhibited by anti-CD4 but not by antiCD8, suggesting that in this clone it is the CD8 molecule that is "uncoupled." These data indicate that the mere presence of CD4 or CD8 molecules is insufficient to convey class I or class II $\mathrm{MHC}$ restriction, which presumably resides in the $\mathrm{T}$ cell receptor.

The suppression mediated by RLB9-7 cells appears to be MHC restricted because RLB9-7 cells were incapable of inhibiting allogeneic PBMC. In contrast, other human suppressor cells have been found to inhibit antibody production by allogeneic PBMC (14). This lack of inhibition was seen even in the presence of autologous antigen-presenting cells, which should have been sufficent to induce activation of RLB9-7 cells. This suggests that suppression was not mediated by nonspecific soluble factors unless the soluble factors were genetically restricted. In addition, we have been unable to induce suppression by the addition of conditioned medium from antigen stimulated RLB9-7 cells (data not shown). Production of IL-2 and $\gamma$-interferon by antigen-stimulated RLB9-7 cells was measured and found to be minimal compared to that reported for CD4 clones (4). This further suggests that suppression was not lymphokine mediated and RLB9-7 cells are not effectors of delayed hypersensitivity. Thus the data indicates that clone RLB9-7 is an urushiol-triggered, nonspecific suppressor clone. Such a clone may represent an important downregulatory mechanism of the delayed hypersensitivity response. It could be significant that this clone was derived from peripheral blood several months after clinical dermatitis. From both animal and human studies there is ample evidence for the involvement of CD4 (L3T4 or T4) cells in the immune response to haptenated self. One may predict that $\mathrm{CD} 4^{+}$urushiol-specific cells could be isolated from either the lesion or the periphal blood during 
an acute immune response and that such $\mathrm{CD}^{+}$cells may mediate the delayed hypersensitivity response. This will be the subject of future investigations.

The suppressor $\mathrm{T}$ cell "cascade" has been extensively investigated in the murine system by the use of synthetic polymers such as glutamic acid-tyrosine and glutamic acid-alanine-tyrosine (29) as well as the hapten 4-hydroxy-3-nitrophenyl acetyl (30). It is reported that there are at least three suppressor cells termed TS1, TS2, and TS3 (31). TS1 is an Lyt-1-positive Lyt2-negative cell (presumably L3T4 ${ }^{+}$), whereas TS 2 and TS 3 are Lyt 2 positive. TS 1 cells produce a suppressor inducer factor (TSF1) which bears I-J determinants and acts in a non-H2-restricted manner to induce TS2 (32). TS2 cells produce a factor (TSF2) which bears I-J determinants and acts in an $\mathrm{H} 2$ (I-J) restricted fashion to induce TS3 (29), the activity of which is restricted by I-J (31). These factors are genetically restricted by $\mathrm{IgH}$ genes (31) as well as being antigen specific. Once TS3 cells are activated, they release $\mathrm{TsF} 3$, which after binding antigen on an $\mathrm{IJ}^{+}$factor presenting cell, mediates nonspecific suppression of the contact sensitivity response.

There is also evidence suggesting a three cell suppressor $\mathrm{T}$ cell "cascade" in humans. Our laboratory has characterized a $\mathrm{CD} 4{ }^{+} 2 \mathrm{H} 4^{+}$cell which acts as a suppressor/inducer cell, interacting with $\mathrm{CD}^{+}$cells to generate suppression (18). It was found that $\mathrm{CD} 4^{+} 2 \mathrm{H} 4^{+}$cells activated in the autologous mixed lymphocyte reaction act in an MHC-unrestricted manner to induce CD8-mediated suppression (33). The $2 \mathrm{H}^{+}$antigen appears to be a critical cell interaction molecule in the above system. In other experiments, it was possible to induce $\mathrm{CD} 8^{+}$ $\mathrm{KLH}$ specific suppressor cells in vitro in the presence of $\mathrm{CD} 4^{+}$ cells (34). These $\mathrm{CD}^{+}$cells were able to suppress antigen-specific antibody production in vitro upon transfer to a fresh responder population. It was determined that this radioresistant $\mathrm{CD}^{+}$suppressor cell required the presence of "fresh" radiosensitive $\mathrm{CD} 8^{+}$cells in the responder population to effect suppression (35). It is uncertain how clone RLB9-7 relates to the above data. RLB9-7 is triggered in an antigen-specific manner to effect nonspecific suppression. Furthermore, RLB9-7 cells are capable of inhibiting IgG production by $\mathrm{CD}^{+}$cells and non-T cells in the absence of additional $\mathrm{CD} 8^{+}$ cells (data not shown), suggesting that RLB9-7 acts as a suppressor effector similar to the TS3 cell in the mouse.

Previous studies have cloned $\mathrm{CD}^{+}$antigen specific cells from the peripheral blood and skin lesions of patients sensitive to nickel sulfate $(4,6)$ or cobalt $(5)$. Many of these clones produced high levels of both IL- 2 and $\gamma$-interferon in response to antigen, suggesting that they are mediators of delayed hypersensitivity. There are also reports of cloning $\mathrm{CD}^{+}$suppressor cells from skin lesions of patients with lepromatous $\mathrm{CD}^{+}$ suppressor cells from skin lesions of patients with lepromatous (anergic) leprosy $(12,13,24)$ and peripheral blood of patients with acute Epstein-Barr virus infection (14). The lepromintriggered suppressor clones share with RLB9-7 the properties of being triggered specifically by antigen to induce nonspecific suppression. In addition, these clones are radiation resistant and $\mathrm{MHC}$ restricted in their triggering. By contrast, the $\mathrm{CD} 8^{+}$ suppressor cells cloned from patients with acute EBV infection were capable of inhibiting antibody production by both PWM-stimulated allogeneic cells and EBV-stimulated autologous cells. These clones were also found to lack NK- and EBV-specific cytotoxicity and appear to be nonantigen specific suppressor cells.
In conclusion, RLB9-7 cells are capable of antigen-dependent, nonspecific suppression of antibody production. Suppression appears to be triggered by recognition of antigen by an $\alpha \beta$ chain $\mathrm{T}$ cell receptor in association with class I MHC. This may represent a mechanism of downregulating delayed hypersensitivity to haptens.

\section{Acknowledgments}

Pure urushiol was the generous gift of Dr. Harold Baer (Food and Drug Administration, Bethesda, MD). Blood from MHC-typed donors was supplied by Dr. Nancy Reinsmoen and Dr. Fritz Bach (University of Minnesota).

Richard S. Kalish was supported by Individual National Research Service Award AM-07804. This study was partly supported by grant AM-33713 from the National Institutes of Health.

\section{References}

1. Kligman, A. M. 1958. Poison ivy (rhus) dermatitis. Arch. Dermatol. 77:149-1980.

2. Dunn, I. S., D. J. Liberato, N. Castagnoli, and V. S. Byers. 1986. Influence of chemical reactivity of urushiol-type haptens on sensitization and induction of tolerance. Cell. Immunol. 97:189-196.

3. Byers, V. S., W. L. Epstein, N. Castagnoli, and H. Baer. 1979. In vitro studies of poison oak immunity. I. In vitro reaction of human lymphocytes to urushiol. J. Clin. Invest. 64:1437-1448.

4. Sinigaglia, F., D. Scheidegger, G. Garotta, R. Scheper, M. Pletscher, and A. Lanzavecchia. 1985. Isolation and characterization of Ni-specific $\mathrm{T}$ cell clones from patients with $\mathrm{Ni}$-contact dermatitis. $J$. Immunol. 135:3929-3932.

5. Lofstrom, A., and H. Wigzell. 1986. Antigen-specific human T cell lines specific for cobalt chloride. Acta. Dermato. Venereol. 60:200-206.

6. Kapsenberg, M. L., P. Res., J. D. Bos, A. Schootemijer, M. B. M. Teunissen, and W. V. Schooten. 1987. Nickel-specific T lymphocyte clones derived from allergic nickel contact dermatitis lesions in man: heterogeneity based on requirement of dendritic antigen-presenting cell subsets. Eur. J. Immunol. 17:861-865.

7. Canonica, C. W., M. Caria, M. Bagnasco, M. E. Cosulich, G. Giordano, and L. Moretta. 1985. Proliferation of T8-positive cytolytic $\mathrm{T}$ lymphocytes in response to thyroglobulin in human autoimmune thyroiditis: analysis of cell interactions and culture requirements. Clin. Immunol. Immunopathol. 36:40-48.

8. Hafler, D., D. S. Benjamin, J. Burks, and H. L. Weiner. 1987. Myelin basic protein and proteolipid protein reactivity of brain and cerebrospinal fluid-derived $\mathrm{T}$ cell clones in multiple sclerosis and postinfectious encephalomyelitis. J. Immunol. 139:68-72.

9. Mesler, L., P. J. Spiess, E. P. Director, and S. A. Rosenberg. 1987. Identification of specific immune responses against autologous tumor in humans bearing malignant melanoma. J. Immunol. 138:989-995.

10. Preffer, F. I., R. B. Colvin, C. P. Leary, L. A. Boyle, T. V. Tuazon, A. J. Lazarovitz, A. B. Cosimi, and J. T. Kurnick. 1986. Two-color flow cytometry and functional analysis of lymphocytes cultured from human renal allografts identification of a Leu- $2^{+} 3^{+}$subpopulation. J. Immunol. 137:2823-2830.

11. Modlin, R. L., V. Mehra, L. Wong, Y. Fujimiya, W. C. Chang, D. A. Horwitz, B. R. Bloom, T. H. Rea, and P. K. Pattengalo. 1985. Suppressor T lymphocytes from lepromatous leprosy skin lesions. $J$. Immunol. 137:2831-2834.

12. Ottenhoff, T. H. M., D. G. Elferink, P. R. Klatser, and R. R. P. de Vries. 1986. Cloned suppressor T cells from a lepromatous leprosy patient suppress Mycobacterium leprae-reactive helper T cells. Nature (Lond.). 322:462-464.

13. Hoffman, R. M., G. R. Pape, P. Rieber, J. Eisenburg, J. Dohrmann, R. Zachoral, G. Paumgartner, and G. Riethmuller. 1986. Cyto- 
lytic T cell clones derived from liver tissue of patients with chronic hepatitis B. Eur. J. Immunol. 16:1635-1638.

14. Wang, F., M. Blaese, K. C. Zoon, and G. Tosato. 1987. Suppressor $\mathrm{T}$ cell clones from patients with acute Epstein-Barr virus-induced infectious mononucleosis. J. Clin. Invest. 79:7-14.

15. Morimoto, C., J. A. Distaso, Y. Borel, S. F. Schlossman, and E. L. Reinherz. 1982. Communicative interactions between subpopulations of human $\mathrm{T}$ lymphocytes required for generation of suppressor effector function in a primary antibody response. J. Immunol. 128:1645-1650.

16. Todd, R. F., S. C. Meuer, P. L. Romain, and S. F. Schlossman. 1984. A monoclonal antibody that blocks class II histocompatibilityrelated immune interactions. Hum. Immunol. 10:23-40.

17. Reinherz, E. L., P. C. Kung, G. Goldstein, and S. F. Schlossman. 1979. Separation of functional subsets of human $T$ cells by a monoclonal antibody. Proc. Natl. Acad. Sci. USA. 76:4061-4065.

18. Morimoto, C., E. L. Reinherz, Y. Borel, and S. F. Schlossman 1983. Direct demonstration of the human suppressor inducer subset by anti-T cell antibodies. J. Immunol. 130:157-161.

19. Morimoto, C., E. L. Reinherz, and S. F. Schlossman. 1981. Primary in vitro anti-KLH antibody formation by peripheral blood lymphocytes in man: detection with a radioimmunoassay. J. Immunol. 127:514-517.

20. Weissman, G., L. Azaroff, S. Davidson, and P. Dunham. 1986. Synergy between phorbol esters, 1-olel-2-acetylglycerol, urushiol, and calcium ionophore in eliciting aggregation of marine sponge cells. Proc. Natl. Acad. Sci. USA. 83:2914-2918.

21. Meuer, S. C., S. F. Schlossman, and E. L. Reinherz. 1982. Clonal analysis of human cytotoxic $\mathrm{T}$ lymphocytes: $\mathrm{T}^{+}$and $\mathrm{T}^{+}$effector $\mathrm{T}$ cells recognize products of different major histocompatibility complex regions. Proc. Natl. Acad. Sci. USA. 79:4395-4399.

22. Arai, K., H. Yamamoto, K. Itoh, and K. Kumagai. 1983. Suppressive effect of human natural killer cells on pokeweed mitogen induced T cell differentiation. J. Immunol. 131:651-657.

23. Griffin, J. D., T. Hercend, R. P. Beveridge, and S. F. Schlossman. 1983. Characterization of an antigen expressed by human natural killer cells. J. Immunol. 130:2947-2951.

24. Modlin, R. L., M. B. Brenner, M. S. Krangel, A. D. Duby, and B. R. Bloom. 1987. T-cell receptors of human suppressor cells. Nature (Lond.). 329:541-545.
25. Seventer, G. A., R. A. W. Van Lier, H. Spits, P. Ivanyi, and C. J. M. Melief. 1986. Evidence for a regulatory role of the T8 (CD8) antigen in antigen-specific and anti-T3 (CD3) induced lytic activity of allospecific cytotoxic T lymphocyte clones. Eur. J. Immunol. 16:1363-1371.

26. Bank, I., and L. Chess. 1985. Perturbation of the T4 molecule transmits a negative signal to T cells. J. Exp. Med. 162:1294-1303.

27. Blue, M. L., D. H. Hafler, J. F. Daley, H. Levine, K. A. Craig, J. B. Breitmeyer, and S. F. Schilossman. 1988. Regulation of T cell clone function via CD4 and CD8 molecules: anti-CD4 can mediate two distinct inhibiting activities. J. Immunol. 140:376-383.

28. Jones, B., P. A. Khavari, P. J. Conrad, and C. A. Janeway. 1987. Differential effects of antibodies to Lyt-2 and L3T4 on cytolysis by cloned, Ia restricted T cells expressing both proteins. J. Immunol. 139:380-384.

29. Kapp, J. A., C. H. Sorensen, and C. W. Pierce. 1983. Antigen specific suppressor T cell interactions II. Characterization of two different types of suppressor $T$ cell factors specific for $L$-glutamic acid-Ltyrosine (GT) and L-glutamic acid-L-alanine-L-tyrosine (GAT). J. Exp. Med. 158:1962-1978.

30. Hausman, P. B., D. H. Sherr, and M. E. Dorf. 1985. An in vitro system for the generation of suppressor cells and the requirement for $B$ cells in their induction. J. Immunol. 134:1388-1396.

31. Dorf, M. E., and B. Benacerraf. 1984. Suppressor cells and immunoregulation. Annu. Rev. Immunol. 2:127-158.

32. Knapp, J. A., and B. A. Araneo. 1982. Antigen specific suppressor T cell interactions I. Induction of an MHC restricted suppressor factor specific for L-glutamic acid-L-tyrosine. J. Immunol. 128:2447-2452.

33. Takeuchi, T., C. E. Rudd, S. F. Schlossman, and C. Morimoto. 1987. Induction of suppression following autologous mixed lymphocyte reaction; role of a novel $2 \mathrm{H} 4$ antigen. Eur. J. Immunol. 17:97103.

34. Morimoto, C., E. L. Reinherz, R. F. Todd, J. A. Distaso, and S. F. Schlossman. 1983. Generation of antigen specific suppressor cells in vitro in man. J. Immunol. 131:i209-1213.

35. Morimoto, C., J. A. Distaso, J. J. Cheney, E. L. Reinherz, and S. F. Schlossman. 1984. Cellular interaction between subsets of T8 population for maximal suppression of antigen specific antibody responses. Cell. Immunol. 88:75-84. 